\title{
Decolonizing, conviviality and convivial conservation: towards a convivial SDG 15, life on land?
}

\author{
Judith E. Krauss ${ }^{1}$ \\ University of Sheffield, UK \\ Preprint Sep 21
}

\begin{abstract}
In their article 'Towards convivial conservation' (2019), Büscher and Fletcher propose a vision for conservation which partly builds on Ivan Illich's 1973 book Tools for Conviviality. Given a growing chorus of voices calling for decolonizing conservation to address the ramifications of racialized mindsets and biases, this article asks: what role could conviviality play in envisioning alternative, decolonizing conservation ideas, particularly for Sustainable Development Goal (SDG) 15? The article first reflects on the case for decolonizing conservation. It then offers an in-depth analysis of Illich's radical ideas as well as subsequent understandings of conviviality, before juxtaposing Illich's ideas with Büscher and Fletcher's suggestions through a decolonizing lens. Finally, the article reviews SDG 15, 'Life on Land', against the backdrop of the prior decolonizing and convivial perspectives. The article argues that Illich's conviviality and related concepts have much to offer in envisioning alternative, decolonizing conservation ideas by promoting grassroots, democratic decision-making, living within bounds by the rich, emphasizing interdependencies between and within people and the environment. But they need to avoid imposition, and incorporate intergenerational and marginalized viewpoints adequately.
\end{abstract}

Key words: decolonizing, conviviality, convivial conservation, Sustainable Development Goal 15, justice

\section{Résumé}

Dans leur article « Towards convivial conservation » (2019), Büscher et Fletcher proposent une vision de la conservation qui s'appuie en partie sur le livre Tools for conviviality (1973) d'Ivan Illich. Compte tenu des voix croissantes qui demandent la décolonisation de la conservation pour aborder les effets des mentalités et réjugés racialisés, cet article pose la question: quel rôle la convivialité pourrait-elle jouer dans la vision d'alternatives décolonisantes pour la conservation, en particulier pour l'objectif de développement durable (ODD) 15? L'article se penche d'abord sur les arguments en faveur de la décolonisation de la conservation. Il procède ensuite à une analyse approfondie des idées radicales d'Illich ainsi que des conceptions ultérieures de la convivialité avant de juxtaposer les idées d'Illich aux suggestions de Büscher et Fletcher à travers une lentille décolonisante. Enfin, l'article analise l'ODD 15, 'vie terrestre', dans le contexte de ces perspectives décolonisantes et conviviales. L'article soutient que la convivialité d'Illich et les idées qui y sont liées ont

\footnotetext{
${ }^{1}$ Dr. Judith E. Krauss, postdoc, SIID, University of Sheffield, UK. Email: judith.e.krauss "at" gmail.com. I would like to acknowledge gratefully support from the NORFACE/Belmont Forum-funded research project 'Convivial conservation' (ES/S007792/1). The views expressed in this manuscript are those of the author alone and do not represent those of any funder or other organization. I thank Dan Brockington and Rosaleen Duffy for helpful comments on various drafts of this manuscript, and Sara Maestre Andrés, Esteve Corbera Elizalde and Dan Brockington for the opportunity to present this article at their 'Conservation, climate change and decolonization' workshop in October 2019 at Autonomous University Barcelona, and for subsequent helpful comments in the editorial process. Thank you to Simon Batterbury and JPE for further help with editing and presentation. Thank you also to workshop attendees and the University of Sheffield's Alternatives to Development reading group for fruitful discussion, as well as to anonymous reviewers for constructive, helpful comments to strengthen the manuscript. Continuous, inspiring conversations on decolonizing, decoloniality etc. with Y Ariadne Collins and Andrea Jiménez Cisneros have been instrumental. All errors remaining are my own. Carbon emissions arising from this article were minimized through rail and coach travel and renewable energy in the home office. S.D.G. This is the xx article in Dan Brockington, Esteve Corbera and Sara Maestre (eds.). 2021. "The challenges of decolonizing conservation", Special Section of the Journal of Political Ecology 28.
} 
beaucoup à offrir pour envisager des idées alternatives et décolonisantes pour la conservation, en promouvant la prise de décision démocratique à la base, demandant des vies entre les limites planetaires par les riches, et en mettant l'accent sur les interdépendances entre et au sein des personnes et de l'environnement. Au même temps, il faut cependant éviter toute imposition externe, et intégrer de manière adéquate les points de vue intergénérationnels et marginalisés.

Mots-clés: décolonisation, convivialité, conservation conviviale, Objectif de Développement Durable 15, justice

\section{Resumen}

En su artículo "Towards convivial conservation" (2019), Büscher y Fletcher proponen una visión de la conservación que se basa en parte en el libro de Ivan Illich de 1973 Tools for conviviality. Dadas las crecientes voces que piden la descolonización de la conservación para abordar los efectos de mentalidades y prejuicios racializados, este artículo pregunta: ¿qué papel podría desempeñar la convivialidad en la visión de ideas de conservación alternativas y descolonizadoras, en particular para el Objetivo de Desarrollo Sostenible (ODS) 15? El artículo reflexiona primero sobre el caso para la descolonización de la conservación. A continuación, realiza un análisis de las ideas radicales de Illich, así como de las posteriores interpretaciones de la convivialidad, antes de yuxtaponer las ideas de Illich con las sugerencias de Büscher y Fletcher mediante una lente descolonizadora. Por último, el artículo analiza el ODS 15, 'vida de ecosistemas terrestres', en el contexto de estas perspectivas decolonizadoras y conviviales. En el artículo se sostiene que la convivialidad de Illich y las ideas conexas tienen mucho que ofrecer para concebir ideas de conservación alternativas y descolonizadoras gracias a sus principios promoviendo decisiones democráticas, rogando vidas dentre de los límites planetários por los ricos, y tomando en cuenta las interdependencias entre las personas y el medio ambiente. Sin embargo, es necesario evitar la imposición externa e incorporar adecuadamente puntos de vista intergeneracionales y marginales.

Palabras claves: descolonización, convivialidad, conservación convivial, Objetivo de Desarrollo Sostenible 15, justicia

\section{Introduction}

The only solution to the environmental crisis is the shared insight of people that they would be happier if they could work together and care for each other. Ivan Illich (1973, p. 50)

In their article 'Towards convivial conservation' (2019) and book The Conservation Revolution (2020), Büscher and Fletcher propose a transformative vision for conservation which partly builds on Ivan Illich's 1973 Tools for Conviviality. Conviviality, as developed by Illich and other scholars in Cuernavaca, Mexico, proposes a society founded on justice and freedom in responsible interdependence, implemented through participatory, democratic decision-making. A convivial society is also founded upon knowledge and tools not serving individualized profit and industrialized production, but the common good, while limiting resource consumption for the rich. This unified vision and related principles have recently inspired increasing debate (e.g. Caillé et al., 2011, Alphandéry et al., 2020). The still-evolving ideas of 'convivial conservation' aim to move beyond recent proposals around 'new conservation' and its market-based antecedents, and the countervailing, vociferous support for exclusion- or restriction-based ideas. Büscher and Fletcher's vision (2019, 2020) instead champions co-existence, biodiversity and justice, and challenges broader drivers of environmental degradation rooted in the primacy of economic growth.

At the same time, there has been intensifying debate about decolonizing policy, practices and research around conservation, the environment and political ecology, calling for conservation ideas and approaches to acknowledge, address and move beyond abiding unequal dynamics rooted in colonial pasts and perpetuated through socio-ecological injustices to the present (cf. this collection; Asiyanbi, 2019; Domínguez \& Luoma, 2020; Kasaona, 2020; Lang, 2018; Mbaria \& Ogada, 2016; Ogada, 2017, 2019; Schulz, 2017, Survival International, 2018; Zanotti et al,. 2020). Illich's conviviality is either at the root of, or contributing to, 
diverse discussions of transformative change away from dominance by industrialist paradigms from the Global North, while convivial conservation (cf. Massarella et al., forthcoming) is also increasingly debated as a radical, transformative option for biodiversity conservation that prioritizes justice. ${ }^{2}$

Consequently, this article asks: what role could conviviality play in envisioning alternative, decolonizing conservation ideas? To what extent can the ideas of conviviality and convivial conservation, with roots in the Global North, serve as decolonial options (Mignolo \& Escobar, 2015, Tlostanova \& Mignolo, 2009)? Can they highlight issues which have arisen as a result of the coloniality-modernity matrix of power, and use decolonial thinking and writing to address them? This is an important question because there is a need to assess how these convivial ideas enable moving beyond top-down conservation paradigms, policies and practices which are rooted in colonial, racialized understandings of human and nonhuman nature and their interrelations, and which perpetuate social and ecological injustices. The article's original contribution is thus analyzing conviviality and convivial conservation through a decolonizing lens. It argues that Illich's conviviality and related ideas have much to offer in envisioning alternative, decolonizing conservation ideas as a unified philosophy: one that promotes grassroots, democratic decision-making, living within limits by the rich, and emphasizing interdependencies between and within humanity and the environment. However, to be fully decolonial options, they need to avoid imposition and must adequately incorporate intergenerational and marginalized viewpoints. After a discussion of positionality and research design, this article starts by making a brief case for decolonizing conservation. It will introduce Illich's and related understandings of conviviality before summarizing Büscher and Fletcher's (2019, 2020) proposals for convivial conservation. It will then situate both proposals' strengths and challenges through a decolonizing lens. A final section outlines how these considerations could be applied to reforming the Sustainable Development Goal 15 (SDG; UN, 2015) dedicated to conserving biodiversity and ecosystems.

\section{Positionality and research design}

I am adding my voice to a growing chorus questioning how we got here, and how conservation can change (e.g., Adeyeye et al., 2019; Kasaona, 2020; Mbaria \& Ogada, 2016; Rodríguez et al., 2007). My considerations come from the position that natural resource conservation is vital given high rates of biodiversity loss (Diaz et al., 2019), while acknowledging that conservation, and indeed any manifestations of decolonial, decolonizing or convivial conservation will not take the same form everywhere. Westerncentric logics continue to dominate the ways nature is understood, and these have widespread ramifications for policy and practice. It is important to question them (Adams \& Mulligan, 2003).

I must acknowledge my own positionality as a white person working for a British university writing about conservation. I am aware of some key risks inherent in this article, including jumping on the decolonizing bandwagon (Moosavi, 2020), and the wider danger of contributions by white scholars (including Illich, Büscher and Fletcher) receiving more attention than those of scholars and knowledgeholders of color. My aim is to reflect the sentiment expressed so aptly by an Aboriginal activist group in Queensland in 1975: "If you have come to help me, you are wasting your time. If you have come because your liberation is bound up with mine, then let us work together" (often ascribed to Lilla Watson alone, but attributed to the collective by her; Toporek, 2013, p. 21). Consequently, I have striven to avoid a neocolonial, recolonizing or appropriating position, by drawing on and giving due credit to diverse authorship and scholarship beyond Northerncentrism (Moosavi, 2020), building on several years of learning from and engaging with decolonizing and decolonial debates (cf. acknowledgements and other co-authored work, e.g. Collins et al., 2021, and Mabele et al., under review).

The case-study of SDG 15 in relation to convivial conservation is appropriate for several reasons. Firstly, the SDGs were meant to be different, after the Millennium Development Goals were formulated by a "small group of rich countries" without input by the global community or from civil-society organizations (Sen \& Mukherjee, 2014, p. 189). The SDGs were originally proposed by government representatives from

\footnotetext{
${ }^{2}$ For more discussion of the kindred concept of environmental justice, please see e.g. Martin et al. (2020) and Menton et al. (2020).
} 
Colombia and Guatemala, explicitly aimed to go beyond previously agreed language (Chasek \& Wagner, 2016), and sought to leave no one behind (UN, 2015, p. 1). However, it has been shown that the SDGs do not fundamentally challenge existing global power asymmetries (Gupta \& Vegelin, 2016) and can contravene decolonial intentions (Hope, 2020b, Krauss et al., under review). The SDGs' relevance for conservation policy is their importance as a global governance paradigm influencing practice and monitoring of progress towards development goals. I focus on the detail of SDG 15 dedicated to terrestrial conservation and ecosystems, illustrating its problems and how we could move beyond it (Maldonado-Torres, 2007). I situate recent interest in conviviality and convivial conservation with regards to broader decolonizing conservation efforts, while providing concrete suggestions for how to distil conviviality and decolonizing principles into a framework that shapes the present and future of conservation in SDG $15 .^{3}$

\section{A brief case for decolonizing conservation}

To discuss conviviality and convivial conservation through a decolonizing lens, it is important to highlight why 'decolonizing conservation' is increasingly debated. It is vital to first clarify what is meant by decolonizing. Fanon $(1963,2002)$ describes with great force of language the abiding, systematic, allencompassing violence perpetrated by colonialism. Across all spheres of life, including education, livelihoods and infrastructure, colonialism created debasing and inhumane hierarchies of difference solely based on skin color, to distinguish between colonizers and the damnés, literally the damned (Fanon, 1963, 2002). This has produced abiding patterns of coloniality and power which affect all human relations, including labor and knowledge production (Maldonado-Torres, 2007). These block genuine mutual learning among equals (Quijano, 2007). Building on Fanon (1963), Tuck and Yang have argued that decolonization is not a metaphor (2012): efforts to diversify curricula in Northern universities cannot be conflated with the violence of settler colonialism and the need to restore land to Indigenous peoples. While it is unclear to what degree Tuck and Yang's (2012) equation of decolonization with repatriating Indigenous land and life is specific to settler colonialism, their reminder of the long-lived pain inflicted by colonialism and colonization is important. Collins's insightful concept of 'colonial residue' (2019) highlights colonization and coloniality manifest in people and societal structures, shaping the ownership and the fate of land and resources, and the structures influencing and implementing these decisions. Collins' work on Guyana and Suriname, profoundly shaped by colonial relations, questions what 'decolonizing' could return to. Here, Maldonado-Torres's (2016) distinction between specific historical periods of colonialism and colonization, and the abiding power dynamics resulting from colonial-and-cognate mindsets, is relevant. In his understanding, decolonial work encompasses efforts to rehumanize the world and break "hierarchies of difference that dehumanize subjects and communities and that destroy nature" (2016, p. 10).

In this spirit, this article uses 'decolonizing' and 'decolonial' interchangeably. Both encompass efforts to break down hierarchies of difference constructed in colonial times, and that persist to this day through racialized power dynamics and perpetuation of socio-ecological injustices. Decolonizing conservation is used as a way to attain the breaking down of colonial structures called for by Maldonado-Torres, while addressing the matrices of power which underlie and result from them. This dual understanding will ensure a focus on the principles and processes of decolonization, rather than seeking to identify any non-colonial point of return. The emphasis on the residues left by colonization and colonial ways of thinking does facilitate attention to decolonial options (Mignolo \& Escobar, 2015, Tlostanova \& Mignolo, 2009): this means using decolonial thinking and writing to identify and address ongoing injustices which are rooted in the past, and linked to land and resources.

Ideas of conservation rooted in colonial, racialized understandings of human and nonhuman nature perpetuate and exacerbate social and environmental injustices for those living or working with conservation

\footnotetext{
${ }^{3}$ The aim is not to offer immediately implementable alternative indicators, since this would go against the participatory processes I highlight as important to drive alternative, social-equity-based notions informing funding and notions of progress. See Zafra-Calvo et al. (2017) for social-equity indicators in conservation and Hidalgo-Capitán et al. (2019), for the alternative 'Good Living Goals'). I acknowledge that my article stops short of using empirical material, like other decolonization literature. I hope to add to this discussion through empirically-based material in future.
} 
in the Global South. Conservation combines diverse movements and world views (Adams, 2003; Chua et al., 2020; Sandbrook et al., 2019). However, some problematic ideas conceived in the Global North have proved pervasive: for instance, romanticized ideals of untouched, 'wild' nature, which were formulated in opposition to the Industrial Revolution, were transferred to the Global South ${ }^{4}$ (Adams and Mulligan, 2003; Plumwood, 2003). They are intricately linked to a dualist separation of humans and nature (Salleh, 2016), equally conceived in the Global North. Among the stricter protected areas, these ideas have consequences for local peoples whose livelihoods can be altered or eliminated by being separated from resources for the sake of preserving 'wild' nature. These dynamics can lead to land in the Global South, and the aspirations of people who live on it, being regarded as less important than imposed conservation ideals (Asiyanbi and Lund, 2020; Kasaona, 2020). This entangled web of European-derived ideas entails significant social, economic and ecological consequences for those living and working with conservation, yet biases around race or gender often go unacknowledged (Adams \& Mulligan, 2003, Duffy et al., 2019; Mbaria and Ogada, 2016). These and other examples are not only problematic in and of themselves for the contexts and peoples involved. Hall's (1992) crucial insight is that the ways that ideas are represented limit other ways of constructing these notions: this means that Eurocentric ontologies, epistemologies, and policy formulations dominate and displace alternative framings which could prioritize Indigenous, decolonial, and justice-focused logics.

Unjust ideas are inextricably linked with knowledge and knowledge production, which are fundamentally imbricated with power (Noxolo, 2017). They start with structures in need of decolonizing in higher education and in pedagogy (e.g. Bhambra, Nişancioğlu \& Gebrial, 2018; Langdon, 2013; Mbembe, 2016; Santos, 2018). Scholars from the Global South have long emphasized the importance of local leadership in setting conservation agendas (e.g. Kothari, 2021; Rodríguez et al., 2007). An open letter with over 230 signatories critiqued the recent debate around 'new conservation' and countervailing protection support, arguing it was formulated by a narrow group of mostly male conservationists from the Global North. Instead they called for a more-inclusive vision, granting equal roles to women and scientists and practitioners of diverse ethnicities and cultures (Tallis, Lubchenco et al., 2014). The types of knowledge recognized and legitimated tend to diminish local expertise, and even participatory forest management predominantly builds on formal, scientific knowledge provided by professional foresters (Sungusia et al., 2020). Conscious, equitable efforts to acknowledge and empower knowledges and knowledge holders beyond a Western canon are vital in any efforts to decolonize conservation (Agrawal, 1995; Chilisa, 2017; Shackeroff \& Campbell, 2007; Zanotti et al., 2020). Indigenous knowledges and labor, central to many conservation and conservation research projects, are characterized by complex, alternating processes of erasure, performance and "survivance"5: stark power asymmetries with conservation actors require careful negotiations with prevailing knowledge systems (Rubis \& Theriault, 2019).

\section{Introducing conviviality}

In 1973, in his influential book Tools for Conviviality, Ivan Illich formulated an explicit vision of a convivial society, i.e., one built on "individual freedom realized in personal interdependence" (1973, p. 12). Alongside survival and the control of work as key conditions for conviviality, Illich names justice, which is commonly "debased to mean the equal distribution of institutional wares" (1973, p. 12), but in fact needs to be both distributive and participatory (1973, p. 38). Rather than equality being in the possession of industrial goods, justice to Illich emphasizes participation in decision-making and creating new images of the future that are not contingent on another person's enforced labor, learning or consumption.

\footnotetext{
${ }^{4}$ I use the terms Global South, and Global North, cognizant that they lump together non-monolithic backgrounds with very diverse historical and contemporary experiences of conservation and justice. They need to be problematized so as not to exacerbate unhelpful binaries or to ignore context specificities and 'Norths within the South/Souths within the North' (cf. e.g., Dirlik, 2007; Wa Ngugi, 2012). I nevertheless use the terms to center the South and the Global South's experiences, given conservation's diverse implications - especially for lives and livelihoods in Southern contexts.

5 Anishinaabe author Gerald Vizenor defines "survivance" as "more than survival, more than endurance or mere response ... survivance is an active repudiation of dominance, tragedy, and victimry" (Vizenor, 1998, p. 15).
} 
Conviviality, which Illich sees explicitly as the opposite of industrial productivity, is "autonomous and creative intercourse among persons, and the persons with their environment" (1973, p. 12). The only limit on freedom is to guarantee another's equal freedoms. It is important to note, however, that freedom for Illich is not understood as maximally free markets in the sense of laissez-faire-economics, but as freedom in responsible interdependence. His thinking rejects 'tools' (understood as all instruments and mechanisms of material and consultative production) being hijacked by elites and experts to reinforce hierarchies and decision-making by the few (cf. Deriu, 2014; Garcia, 2009). Instead, Illich emphasizes the significance of broad-based participatory processes: for safeguarding individual's access to communal tools, and for reaching social agreements. In short, conviviality is a passionate appeal not to cede control of society to the few, but to encourage the many to reach agreements that enhance individual freedom cognizant of interdependencies between people, but also with the environment and planetary limits (Barkin, 2019). To Illich, this convivial vision was not only a line of thinking, but a vocation (Atasay \& Bourassa, 2013). It incorporated inclusive, broad-based decision-making, justice considering all human and environmental interdependencies, and curtailed resource consumption by the rich. This strength of conviction may account for why his ideas inspire scholars to this day, to build transformative visions (e.g. Caillé et al., 2011, Alphandéry et al., 2020).

Following study in Austria and the Vatican, and his work as a priest with Puerto Ricans in North America, Illich expressed sharp criticism of the institutionalization of religion. He saw the roots of Western modernization and industrialization as interlinked (Mert, 2015). Illich's book, Tools for Conviviality (1973), resulted particularly from conversations at the research center in Cuernavaca, Mexico, which he helped establish. Illich's thoughts are fundamentally radical in terms of questioning commonly accepted pillars of the world's systems, such as compulsory education or industrialized lifestyles (Zaid, 2011). This predilection for doubting the bigger picture is reflected and rooted in Illich's vocal criticism of the Western-centric RomanCatholic church, and his critique of modernization as manifest in the developmentalist paradigm of the Truman years. He considered its export to Latin America to be disastrous (Hornedo, 2002; Olvera \& Márquez, n.d.).

Since the heyday of his writing in the 1970s, Illich's work has inspired many. Illich's thoughts on deschooling society (1971) have sparked debate among education scholars for decades (e.g. Gintis, 1972; Narodowski \& Botta, 2017) and, in combination with his ideas on conviviality, raise questions about knowledge being made freely available online (Hart, 2001; Jandrić, 2014). Computer pioneers such as Lee Felsenstein were inspired by Illich to make computers available and accessible to ordinary people rather than just to the technological elite (Isaacson, 2014); arguably, open-source software is the embodiment of convivial tools (Janaszek, 2010). Equally, for scholars of bioethics (Garcia, 2009) and degrowth (Espejo, 2011), conviviality resonates in terms of recognizing human, social and environmental interdependencies and limits. Caillé et al.'s dialogues on the convivial society which is to come (2011) was further developed into the Convivialist Manifesto: declaration of interdependence, which was signed by French-speaking authors from over ten countries. It recognizes interdependence among humans and with the environment (Alphandéry et al., 2013). This has since been developed into a second, more internationally oriented convivialist manifesto which imagines, and aims to inspire concrete steps towards, a post-neoliberal future in light of youth mobilization, and tackling climate change and the erosion of humanist ideals (Alphandéry et al., 2020).

Some thinkers discuss conviviality without reference to Illich. Bauman's (2013) modus covivendi, i.e. negotiating living with people of divergent mindsets, has some parallels, but no explicit reference. Hinchliffe and Whatmore (2006) side with more posthumanist understandings of conviviality (e.g. Castree \& Nash, 2004), citing Illich's perceived (more implicit than explicit) focus on the environment as a reason to look beyond his work. Instead, they develop a 'politics of conviviality' to negotiate the messiness of living together with more-than-humans in urban spaces (2006), which is another source of inspiration for Büscher and Fletcher (2019, 2020). However, my focus is Illich's conviviality, because of the abiding transdisciplinary relevance of his thinking (cf. e.g., Caillé et al., 2011). It has popularity as a value-based and ethics-based tool (Hidalgo-Capitán \& Cubillo-Guevara, 2017), it tackles the excessive consumption of the rich, as well as justice and participation in a unified way, and has intellectual parallels with decolonization. Illich's work is unique, compared with other versions of conviviality. 
Different authors have traced the links between Illich's thinking and two much-discussed philosophies in the decolonial space: buen vivir (Giarracca, 2010; Cortez, n.d.) and Ubuntu (Inman, 1999; Shizha, 2016). Albó (2011) illustrates that the Aymara notion of suma qamaña or vivir bien/buen vivir, means to live, dwell, rest and care for others in a good, generous manner. A second, important pillar is living well with nature, Mother Earth or Pacha Mama. In combination, the two mandate that the world should not revolve around economic growth, but around human growth, and that humans should accept a strong sense of reciprocity with and be a harmonious part of Pacha Mama (Albó, 2011). This is while recognizing that economic, political and social power structures are significant barriers to the implementation of these principles. The idea of suma qamaña is thus embedded within intense convivial reciprocity between people and nature, going far beyond material connections. This extends equally to the notion of just resource extraction limits, and the prioritization of ethical values over economic values (Giarracca, 2010), both of which parallel Illich. Equally, there are parallels between conviviality and Ubuntu, which Chemhuru (2019) defines as a philosophy from southern Africa that, unlike much Western thought, starts with communities and their interconnectedness rather than the individual. 'Umuntu Ngumuntu Ngabantu', derived from the Nguni people - Xhosa, Ndebele and Zulu (Le Grange, 2019) - is understood to be its quintessence, meaning a person is a person through another person (Naicker, 2011, p. 458). A person is understood through the triad between those who have passed, those who are alive, and those who are yet to come (Terblanché-Greeff, 2019). This ethic of care extends beyond humans towards the physical and natural world (Chibvongodze, 2016; Ewuoso \& Hall, 2019), which constitutes a key parallel to Illich's conviviality (Inman, 1999). Scholars including Naicker (2011) and Terblanché-Greeff (2019) emphasize that Ubuntu, given its inclusive, interdependent premise, is well-suited to capture and promote the voices of under-heard communities in global discussions around environmental change. This parallels Illich's emphasis on giving a voice to all, including the least heard. Illich's understanding of conviviality thus converges with buen vivir and Ubuntu on resource consumption limits for the rich, as well as principles of joint, participatory decision-making as part of a commitment to responsible, just interdependence with humans and the environment.

What makes Illich's conviviality attractive as a decolonial option for conservation, and enriching to existing decolonizing debates, is tapping into an existing, unified approach that incorporates several crucial elements as integral, equal parts of cohabitation. Firstly, it emphasizes the conviviality of humans with their environment as a form of freedom in responsible interdependence. For conviviality to succeed, prior agreement on this concept of mutual responsibility between and within people and the environment is crucial. Convivial approaches do not equate to 'anything goes', which would violate the notion of mutual responsibility on which Ubuntu and Illich converge. Secondly, it involves challenging the excesses of industrial production and resource extraction by the rich, akin to buen vivir, to rein in industrial growth as well as to challenge the schism between those who have too much and those who don't have enough. Thirdly, Illich's conviviality makes equity compulsory, rather than optional, emphasizing that living together well is predicated on distributive and participatory justice. Finally, it promotes the type of grassroots decision-making and consultation that has long been championed for marginalized people, but rarely implemented in conservation schemes (Kiwango \& Mabele, under review; Adeyeye et al., 2019). The unified commitment to limit resource consumption and promote justice and inclusive democracy are all integral pillars of Illich's thinking in a way that is absent from much dominant conservation thinking (Krauss, under review), inspiring alternative ideas.

\section{Introducing convivial conservation}

Over the past decade, 'new conservation' has been advocated to save nature, especially by Kareiva, et al. (e.g. Marvier, Kareiva \& Lalasz, 2012). They argue that in an era of perhaps unstoppable large-scale anthropogenic change, embracing the opportunities it creates, such through as corporate partnerships, is the model to promote much-needed biodiversity conservation. This approach, which arguably builds on prior market-based conservation ideas, was met with resistance by a countervailing movement favoring instead a renewed commitment to protecting nature by excluding people from it and restricting use (e.g. Wuerthner et al., 2015). Convivial conservation, building partly on Illich's conviviality, aspires to move beyond both these 
paradigms and their antecedents, but is also a response to the bigger political-economic picture, in which certain political imaginaries increasingly favor anti-environmentalist, nationalist and arguably anti-grassroots stances.

Büscher and Fletcher (2019, 2020), in the first element of the convivial conservation vision, propose moving from protected to promoted areas, which are "fundamentally encouraging places where people are considered welcome visitors, dwellers or travellers" (2020, p. 92). This chimes with the second proposal, shifting from saving nature to celebrating human and nonhuman nature, discarding the idea that certain humans should save nonhuman nature from certain other humans who need to be excluded from it, and instead championing both human and nonhuman nature as special and unique in recognition of their diverse needs and interdependencies. A third aspect concerns shifting from touristic voyeurism to engaged visitation, proposing that seeing 'wild' nature should not be a short-term elite privilege but a long-term democratic engagement based on the principles of socio-ecological justice and degrowth. A fourth aspect emphasizes the importance of overcoming 'spectacular' nature and commodified images in favor of everyday environmentalisms (cf. Cronon, 1996, on what nature to aspire to). A final suggestion concerns moving away from privatized expert technocracy to common democratic engagement, and from monetized value to a nonmonetized 'embedded value' through humans and nonhumans living together, much in the spirit of 'areas conserved by Indigenous peoples and local communities' (ICCAs; Borrini-Feyerabend and Campese, 2017).

To their credit, Büscher and Fletcher $(2019,2020)$ also develop their vision into proposals for concrete actions. These encompass:

- historic reparations, i.e. compensating marginalized communities for past injustice perpetrated in the name of conservation;

- a conservation basic income for community members in or around protected areas to lead a locally defined decent life;

- rethinking (relations with) corporations, given the need for a different economic model prioritizing extraction limits and eventually degrowth;

- a global 'convivial conservation coalition' promoting just conservation.

Finally, Büscher and Fletcher's (2019, 2020) theory of change entails, firstly, thinking about power as both structural and dispersed, while advocating for a co-constitutive understanding of structural power and the power of agency in organizing resistance to effect structural change at all levels. A second aspect of their theory of change are actors, and they categorize differential historical and contemporary responsibilities within conservation into four classes, to emphasize the role of extralocal actors in putting pressure on biodiversity. These are the upper classes (i.e. global elites), land-owning capitalist classes, middle and lower classes, and lower rural classes. The third aspect, time, involves short-term and longer-term steps to attain the convivial conservation vision. Somewhat akin to Illich's conviviality, what could make convivial conservation attractive as a decolonial option in conservation is the critical stance towards the status quo given historical inequities, a commitment to justice through participatory, democratic decision-making and challenging the human-nature separation, while making an effort to offer concrete alternative suggestions. Although it is important to stress that these ideas are still evolving, the following section will query in more detail how these positive proposals link to conviviality and broader decolonizing principles.

\section{Conviviality and convivial conservation as decolonial options?}

Table 1 (below) is a summary of key convergences and divergences between Illich's notion of conviviality, and Büscher and Fletcher's convivial conservation (2019, 2020). I use this as a precursor to discussing some problematic points and omissions across both approaches. 


\begin{tabular}{|c|c|c|}
\hline & Illich's conviviality & Büscher \& Fletcher's convivial conservation \\
\hline $\begin{array}{l}\text { Parallel: radical } \\
\text { aspirations }\end{array}$ & $\begin{array}{l}\text { - challenge tenets of society: industrialized production, elite decision- } \\
\text { making in favor of justice, participation } \\
\text { - freedom = creative, autonomous intercourse for people and nature }\end{array}$ & $\begin{array}{l}\text { - challenges Western-inspired dualistic separation of people and } \\
\text { nature } \\
\text { - celebrates human/nonhuman nature; appreciative } \\
\text { interdependence } \\
\text { - challenges the Capitalocene, i.e. capitalism-driven large-scale } \\
\text { changes to nature and Earth that result from the 'age of } \\
\text { capitalism' }\end{array}$ \\
\hline $\begin{array}{l}\text { Parallel: participatory } \\
\text { decision-making }\end{array}$ & $\begin{array}{l}\text { - skepticism towards elite-owned, non-participatory decision-making } \\
\text { - tools (= all knowledge/all governing mechanisms) need to serve the } \\
\text { common good } \\
\text { - but: how to identify and address hierarchies within communities (cf. } \\
\text { below)? }\end{array}$ & $\begin{array}{l}\text { - move away from governance by top-down, expert opinions } \\
\text { - shift from protected to promoted areas (protected areas can be } \\
\text { unjust) } \\
\text { - engaged visitation } \\
\text { - does not mean "anything goes" } \\
\text { - support for conservation areas governed by Indigenous and } \\
\text { community groups (ICCA), but: how to learn from reported } \\
\text { challenges in community-based conservation linked to genuine } \\
\text { participation? How to identify and address hierarchies within } \\
\text { communities? }\end{array}$ \\
\hline $\begin{array}{l}\text { Parallel: Messiness \& } \\
\text { conflict }\end{array}$ & $\begin{array}{l}\text { - conflict: not competition for scarce resources, but can create new } \\
\text { freedoms and avenues through negotiated, convivial disagreement }\end{array}$ & $\begin{array}{l}\text { - living together can get messy (cf. Paulson, 2001; Hinchliffe \& } \\
\text { Whatmore, 2006) }\end{array}$ \\
\hline $\begin{array}{l}\text { Divergence: Living } \\
\text { within bounds }\end{array}$ & $\begin{array}{l}\text { - the rich must live within bounds } \\
\text { - "Significant benefits for the poor demand a reduction of the resources } \\
\text { used by the rich, while significant benefits for the rich make murderous } \\
\text { demands on the resources of the poor" (1973, p. 68) } \\
\text { - how to move away from conservation paradigms shaped by Illich's } \\
\text { 'the rich'? How to avoid the murderous demands on the resources of the } \\
\text { poor from past approaches'? [including both i) market-based } \\
\text { conservation approaches: payment for ecosystem services/REDD+, } \\
\text { Lund et al., 2017; Börner et al., 2017; and ii) restriction-based } \\
\text { approaches: human-wildlife conflict or crop-raiding around strict } \\
\text { nature reserves/protected areas (Tumusiime \& Vedeld, 2012; } \\
\text { Brockington \& Wilkie, 2015; Domínguez \& Luoma, 2020)] }\end{array}$ & $\begin{array}{l}\text { - Could have been more explicit, but supports degrowth and a } \\
\text { call for consideration of deeper, international drivers of } \\
\text { environmental degradation } \\
\text { - Could differentiate more how and which humans, in terms of } \\
\text { their racialized, gendered and power-laden differences and } \\
\text { asymmetries, drive the large-scale changes to nature subsumed } \\
\text { as the Anthropocene (Collins, 2021) }\end{array}$ \\
\hline
\end{tabular}




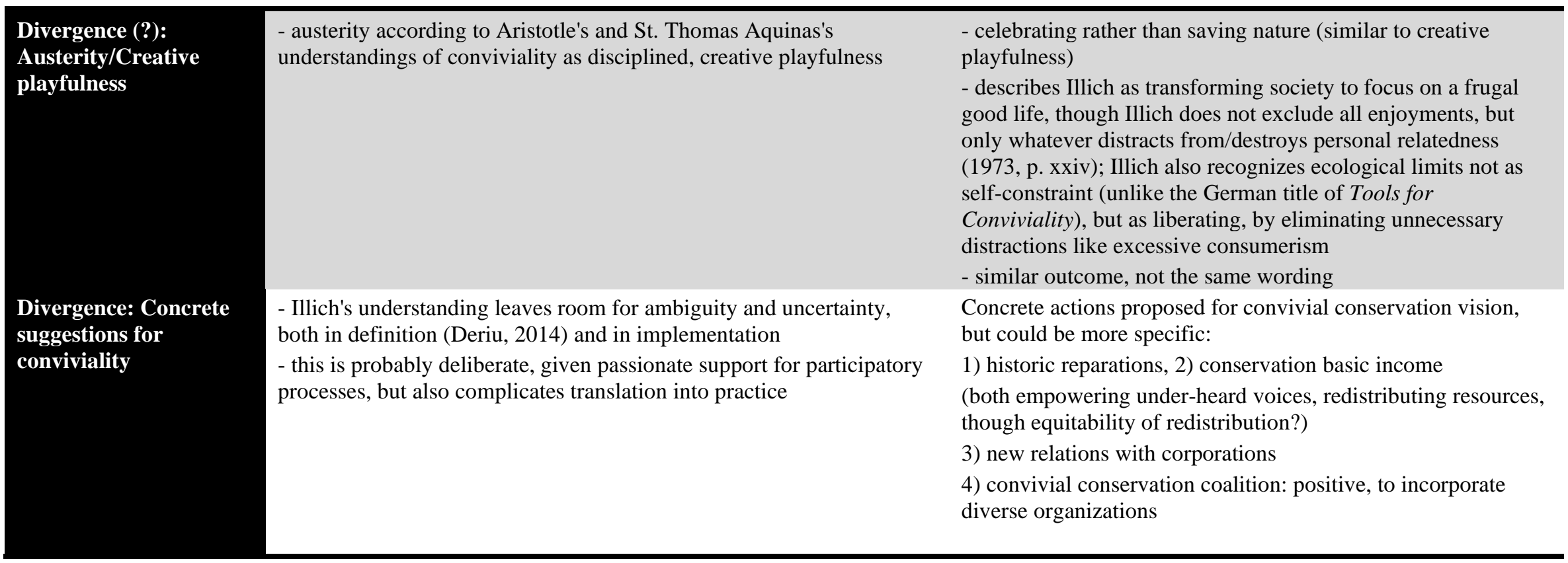

Table 1: Summarizing parallels and divergences between Illich's (1973) conviviality and Büscher and Fletcher's (2019, 2020) convivial conservation. Source: Author. 
A recurring theme across these convergences and divergences is that neither approach to conviviality provides full details on how these positive ideas are to be implemented, in ways that further decolonial thought and challenge and overcome hierarchies of difference. On the one hand, the lack of detail somewhat alleviates the risk of these suggestions, which have roots in the Global North, being imposed without allowing for the necessary, locally driven decision-making which both convivialities advocate and which is in keeping with the decolonial objection to universal solutions (Connell, 2007). On the other hand, this lack of definitive answers could also hamper practical implementation of these ideas at all scales as effective, inclusive decolonial options. For instance, there is a considerable literature detailing the successes and challenges of community-based conservation schemes in involving and empowering local residents. Büscher and Fletcher $(2019,2020)$ do not discuss in much detail how diverse efforts in the community-based conservation space have proved instructive for designing and implementing their vision, outside of expressing their support for conservation areas governed by Indigenous and community groups. In particular, it is vital to know more about how they aim to address reported challenges surrounding community-based conservation including formalization potentially causing local residents to lose access and rights (Hajjar et al., 2021), areas being hampered by imperfect devolution of capacities and funding (Kiwango \& Mabele, under review; Tran et al., 2020), or struggles with elite capture or abiding state control (Noe \& Kangalawe, 2015). Fundamentally, challenging power asymmetries is premised on acknowledging hierarchies at all levels, including within communities and households, with care needed not to idolize 'community' ideas (Agrawal \& Gibson, 1999; Brockington, Duffy \& Igoe, 2008). Further elaboration is necessary because Illich, Büscher and Fletcher, are limited in terms of explicitly emphasizing and highlighting ways to address these hierarchies within communities and households.

Similar uncertainties remain around the specificities of mechanisms to implement Büscher and Fletcher's (2019, 2020) historic reparations, which they acknowledge are difficult issues and must be resolved in context-specific ways. They discuss communities receiving their land back, but again without detailing how unequal power dynamics within communities would be accounted for in this redistribution, or how the interests of future generations would be considered. Finally, while both convivialities acknowledge conflict and messiness in living together, further details remain to be developed on mechanisms to mitigate and manage human-human and human-nonhuman conflict in an equitable, convivial spirit that is cognizant of historical-political contexts. While the convivialist manifesto (Alphandéry et al., 2013) lists 'managed conflict' as one of its four core principles (Humbert, 2017), this would also need to be operationalized both between humans and between humans and wildlife in ways that take account of environments that are often fraught with violence and oppression (Lorimer, 2010; Duffy, 2014).

Beyond these convergences and divergences, there are problematic points in Illich's conviviality which Büscher and Fletcher's (2019) work either replicates or arguably neglects to address sufficiently. Zaid (2011), referencing the Kantian put-down that some people see things very clearly once they have been told where to look, contests the view that Illich's extraordinary perspicacity was in 'knowing which way to look.' While that assertion is generally true, some peculiar blind spots exist which are present in spirit, but not in explicit wording in both forms of conviviality: the first is gender. While Illich's later work (e.g. 1981, 1982) very explicitly draws attention to women's often hidden and underappreciated contributions to society, Tools for Conviviality is silent on the role women play, although Illich's support of participatory processes implicitly recognizes their expertise and voice. Büscher and Fletcher's (2019, 2020) work, equally, does not problematize gender, though their participatory stance parallels Illich's in spirit. Considering gender in local conservation to facilitate equitable participation of women especially, requires explicit attention and welldesigned processes cognizant of factors including access criteria, and distribution of costs and benefits from participation and joint management (Agarwal, 1997; Meinzen-Dick \& Zwarteveen, 2001; Mukadasi \& Nabalegwa, 2007; Sundberg, 2004). In light of decolonial calls to challenge the modern-colonial capitalist system of gender relations (Lugones 2010, 2020), this lack of explicit engagement with gender is a problematic blind spot if power asymmetries are to be challenged through participation, including within communities and households.

Indigenous knowledges are more implicit than explicit in both elaborations of convivialities. As discussed above, knowledge production is imbricated in power dynamics (Noxolo 2017), and challenging 
Eurocentric ways of viewing, measuring and naming the world is vital for decolonization (Freire, 1987; Madianou, 2019; Quijano, 2000; Tuhiwai Smith, 2012). Although Illich does not mention Indigenous knowledge production explicitly, his conviviality is committed to facilitating participatory knowledge access and production across all disciplines, and rejects producing knowledge only for the elite and for supporting industrialization and development. Similarly, there is limited discussion of knowledge production, and specifically the role that Indigenous and non-Western knowledges play in convivial conservation. Büscher and Fletcher's proposals $(2019,2020)$ privilege Indigenous voices particularly in areas governed by Indigenous and conservation groups, while the fifth element of the convivial conservation vision explicitly draws on Indigenous knowledge in developing local and extra-local embedded value, rather than Northern monetized value. While these perspectives are present in spirit, they merit highlighting as points to develop more explicitly from a decolonizing viewpoint.

One final silence of both arguments for convivialities is intergenerational justice, rendered all the more important by rapidly advancing climate change and biodiversity loss. Given that future generations do not have a seat at the table, how can their freedoms and dependence on present-day behaviors factor into decolonial and participatory decision-making processes? This issue is addressed by Ubuntu where past, present and future generations are seen as interdependent. How can this be achieved, especially in the - often Global Southern - areas likely to be most affected by environmental degradation? Ironically, the oftcriticized 1987 Brundtland report delivering the best-known definition of sustainable development, and highlighted the importance of meeting the needs of the present without jeopardizing future generations' ability to do the same (WCED, 1987). While Illich is entirely silent on the matter, Büscher and Fletcher (2019, 2020) express their solidarity with youth, post-colonial, Indigenous and emancipatory movements. However, in Büscher and Fletcher's (2019) theory of change, time is conceptualized as a function of change; there are no explicit considerations of how the proposed convivial conservation suggestions will benefit future generations. In fact, there is a more explicit consideration of the past, through reparations for conservation injustices, than of the future (Büscher and Fletcher, 2020, pp. 103-104), although the objective of changing the economic paradigm and humanity's relation to nature is to improve the socio-environmental context long-term.

In sum, in order for convivial ideas to be fully actualized in conservation as decolonial options, some key lessons emerge. Conviviality and convivial conservation crucially converge on the importance of radical change, the involvement of participatory decision-making privileging under-heard voices, and the messiness of living together, requiring equitable resolutions. Conviviality's emphasis on the rich not making murderous demands on the resources of the poor is a pertinent reminder of one buen-vivir-linked motivation for decolonizing conservation. The implications of this idea, also in light of historical contributions to anthropogenic environmental change (Collins, 2021), merit fleshing out more fully within convivial conservation proposals. Among the most notable silences in both convivialities are the lack of explicit attention to gender, Indigenous knowledge, and intergenerational justice, all of which are important vectors according to decolonial thinking. While convivial conservation usefully takes steps to propose concrete actions, further work remains to be done in applying both convivialities to local contexts, as the details and specificities of such decision-making or research processes co-determine the degrees to which they are able to address and overcome hierarchies of difference along lines of race, gender, age, status or (dis)ability. Crucial challenges thus remain around co-developing convivial, locally suitable participation mechanisms which privilege under-heard voices and avoid reinforcing power inequalities, while upholding Illich's ideas of agreed, reciprocal responsibility for shared resources as Büscher and Fletcher themselves emphasize (2020). All these laudable objectives will require genuinely convivial, inclusive implementation processes that avoid external imposition and replicating local or global power asymmetries (Kothari, 2021).

\section{Towards a convivial SDG 15?}

For people seeking to develop convivial and decolonizing alternatives for conservation, SDG 15, Life on land, is a prominent challenge. The United Nations' SDGs can institutionalize prioritizations of what is to be "saved" and how, which can entail significant implications for conservation policy and practice locally. 
International paradigms including world heritage sites (Noe, 2019). As an agreed global governance framework, the SDGs exemplify Hall's (1992) crucial point that 'framings' can frustrate other ways of constructing topics. To challenge their predecessors, the Millennium Development Goals which were formulated by rich countries (Sen \& Mukherjee, 2014), the SDGs were developed based on governmental support and input from civil-society organizations (Ibrahim, 2018), though making contributions to them was complex (Long, 2018). Nevertheless, questions have been raised about whether the SDGs still replicate hegemonic, dominant notions privileging the privileged, e.g. by prioritizing the interests of agribusiness (Spann, 2017), advancing a highly contested variant of neoliberal, capitalist development (Weber, 2017), and functioning as anti-politics (Hope, 2020a) e.g. in undermining decolonial territorial agendas through a strengthened consensus between powerful actors (Hope, 2020b). Table 2 is a brief summary of SDG 15. It building on an analysis of the ideas of conservation present in SDG 15 (Krauss, under review). I will critique SDG 15 from convivial (conservation) and decolonial viewpoints, and formulate some alternative suggestions ${ }^{6}$, as a contribution to on-going review processes around the SDGs.

Firstly, from the viewpoint of conviviality, SDG 15 does not implement Illich's aspiration to live within means, particularly for the rich. There is very little in SDG 15 or indeed the SDGs more generally that engages with any kind of limits, never mind specific limits for the already rich in terms of Illich's fundamental dichotomy (Lim et al., 2018; Krauss et al., under review). In Illich's conviviality proposal, sharing resources equitably is vital. A convivial principle would therefore be respecting ecological limits globally, beyond specific hotspots, while safeguarding equitable distribution of resources between currently privileged and non-privileged. This would equally align with decolonial thinking, particularly with Ubuntu's respect for unborn generations contributing the vital intergenerational-justice dimension. In keeping with qamaña (Albó, 2011) and Ubuntu (Naicker, 2011), responsibility for other people would go hand in hand with responsibility for the planet, far beyond the protected areas and biodiversity hotspots on which many SDG 15 indicators focus.

From the perspective of convivial conservation, SDG 15 does not sufficiently promote rights and decision-making of residents, rural peoples and the disenfranchised. The Convention on Biological Diversity's 2011-20 strategic targets for biodiversity contain a target, Target 11, which explicitly references the needs of women, Indigenous and local communities and the poor and vulnerable. Despite the Indigenous Peoples' Major Group calling for awareness of Indigenous rights and disaggregation of indicators and data for Indigenous peoples (2015), there is no such commitment in SDG 15, not even an explicit connection to the - in itself limited - reference to participatory governance in SDG 16.7. Not making an explicit commitment in SDG 15 - either overall or for protected areas - to bolstering all types of under-heard communities, including women, ignores the relevance of institutions, for example protected areas, in distributing fortune and misfortune (Brockington and Wilkie, 2015). Consequently, Büscher and Fletcher (2019) propose democratic decision-making arrangements wherever possible, which would equally align well with conviviality and decolonizing.

\footnotetext{
${ }^{6}$ These principles can only be offered as starting points. To support a pluriversal approach, i.e. building a world in which many worlds fit (cf. Conway \& Singh, 2011; Demaria \& Kothari, 2017; Escobar, 2011), these ideas are not meant to be prescriptive, but are to begin a conversation which avoids the risk of replacing one set of external agendas with another (Kothari, 2021), a key concern for all decolonizing debates. Crucially, these conversations must bring together voices which have long been under-heard, i.e. Indigenous and local communities, women and marginalized voices including those of people with disabilities, in a way that respects non-Western knowledges and individuals. At the same time, reaching social agreements which respect the interdependencies of people, environment and future generations. Devising such a conversation process in itself will be challenging, as would implementing the outcomes.
} 


\section{SDG 15: Protect, restore and promote sustainable use of terrestrial ecosystems, sustainably manage forests, combat desertification, and halt and reverse land degradation and halt biodiversity loss}

15.1 By 2020, ensure the conservation, restoration and sustainable use of terrestrial and inland freshwater ecosystems and their services, in particular forests, wetlands, mountains and drylands, in line with obligations under international agreements

15.2 By 2020, promote the implementation of sustainable management of all types of forests, halt deforestation, restore degraded forests and substantially increase afforestation and reforestation globally

15.3 By 2030, combat desertification, restore degraded land and soil, including land affected by desertification, drought and floods, and strive to achieve a land degradation-neutral world

15.4 By 2030, ensure the conservation of mountain ecosystems, including their biodiversity, in order to enhance their capacity to provide benefits that are essential for sustainable development

15.5 Take urgent and significant action to reduce the degradation of natural habitats, halt the loss of biodiversity and, by 2020, protect and prevent the extinction of threatened species

15.6 Promote fair and equitable sharing of the benefits arising from the utilization of genetic resources and promote appropriate access to such resources, as internationally agreed

15.7 Take urgent action to end poaching and trafficking of protected species of flora and fauna and address both demand and supply of illegal wildlife products

15.8 By 2020, introduce measures to prevent the introduction and significantly reduce the impact of invasive

alien species on land and water ecosystems and control or eradicate the priority species

15.9 By 2020, integrate ecosystem and biodiversity values into national and local planning, development processes, poverty reduction strategies and accounts

15.a Mobilize and significantly increase financial resources from all sources to conserve and sustainably use biodiversity and ecosystems

15.b Mobilize significant resources from all sources and at all levels to finance sustainable forest management and provide adequate incentives to developing countries to advance such management, including for conservation and reforestation

15.c Enhance global support for efforts to combat poaching and trafficking of protected species, including by increasing the capacity of local communities to pursue sustainable livelihood opportunities

Table 2: SDG 15 and targets. (UN, 2015, pp. 15-16)

From a decolonizing viewpoint, another key shortcoming in SDG 15 is perpetuating conservation trajectories which have reproduced socio-ecological injustices and power asymmetries. SDG 15 relies 
variously on protected areas, i.e. risking the replication of problematic dynamics of restriction and exclusion (SDG 15.1, 15.2, 15.4), which arguably furthers the suggestion that as long as natural resources can be protected from certain humans, all shall be well. That is a colonial conservation model. At the very least, incorporating social-equity indicators into SDG 15's conservation management should have been vital (cf. e.g. Zafra-Calvo et al., 2017).

A flaw in SDG 15 on which both convivialities and decolonizing converge is that it lacks recognition of interdependencies between and within humans and the environment. There is a general issue with 'siloing' in the SDGs, which identify 17 separate goals without much consideration of interlinkages or trade-offs between them (Pradhan et al., 2017). This recurs with SDG 15's overall goal, which delineates different resources: "Protect, restore and promote sustainable use of terrestrial ecosystems, sustainably manage forests, combat desertification, and halt and reverse land degradation and halt biodiversity loss" (UN, 2018). Similarly, SDG 15's twelve targets and their indicators fail to acknowledge links with other SDGs, for example around poverty (SDG 1) or economic growth (SDG 8) - despite conservation having frequently occurring and substantive implications for nearby communities. As none of the Goals can be addressed in isolation, a convivial and decolonizing alternative would need to recognize systematically the many interconnections between resources and SDG themes, so as to reflect and capture the many interdependencies between the social, economic and environmental aspects of conservation (cf. Toomey, 2020).

\section{Conclusion}

This article has explored what role conviviality could play in envisioning alternative, decolonizing conservation ideas. After some considerations on positionality and research design, I made a brief case for decolonizing conservation in light of the socio-ecological injustices which racialized understandings of human and nonhuman nature and their interrelations entailed, through colonization and through continued colonialities of power and knowledge.

In a second step, I looked at the work of Ivan Illich on conviviality and related iterations of the concept, juxtaposing it with Büscher and Fletcher's (2019, 2020) convivial conservation approach. There are parallels, divergences and omissions, and the suitability of both concepts as decolonial options were explored. Finally, SDG 15 was examined both convivial and decolonizing viewpoints, emphasizing shortcomings around a firm commitment by the Global North to live within bounds (conviviality), participatory decision-making privileging under-heard voices (convivial conservation), and a risk of perpetuating unjust trajectories through a reliance on protection and exclusion (decoloniality).

The article has argued and demonstrated that Illich's conviviality and related ideas offer a unified philosophy that has much to offer. Both arguments for conviviality discussed in this article emphasize the grassroots perspective, democratic decision-making, constraining resource use by the affluent, and interdependencies between and within people and the environment. Both approaches converge, crucially, on the need for radical transformations of the status quo, the importance of participatory decision-making privileging under-heard voices, and the messiness of living together, requiring equitable solutions. Conviviality is insistent that the rich must make far less demands on the resources of the poor, in light of their historical contributions to anthropogenic environmental change (Collins, 2021). This needs greater attention in convivial conservation proposals. To be actualized fully as decolonial options, both forms of conviviality need to address gender differences, Indigenous knowledges, and intergenerational justice much better. While convivial conservation makes concrete suggestions for change, further work remains to be done in applying both convivialities to local contexts. Addressing and overcoming hierarchies of difference along axes of race, gender, age, status or (dis)ability needs greater specificity. These laudable objectives will require genuinely convivial, inclusive implementation, avoiding the replication of local or global power asymmetries (Kothari, 2021). 


\section{References}

Adams, W. M. (2003). Nature and the colonial mind. In W.M. Adams \& M. Mulligan (Eds.), Decolonizing nature: Strategies for conservation in a post-colonial era (pp. 16-50). Earthscan.

Adams, W. M., \& Mulligan, M. (2003). Introduction. In W.M. Adams \& M. Mulligan (Eds.), Decolonizing nature: Strategies for Conservation in a Post-Colonial Era (pp. 1-15). Earthscan.

Adeyeye, Y., Hagerman, S. \& Pelai, R. (2019). Seeking procedural equity in global environmental governance: Indigenous participation and knowledge politics in forest and landscape restoration debates at the 2016 World Conservation Congress. Forest Policy and Economics 109, 102006, https://doi.org/10.1016/j.forpol.2019.102006.

Agrawal, A. (1995). Dismantling the divide between Indigenous and scientific knowledge. Development and Change, 26: 413-439. https://doi.org/10.1111/j.1467-7660.1995.tb00560.x

Agrawal, A., \& Gibson, C. C. (1999). Enchantment and disenchantment: The role of community in natural resource conservation. World Development 27 (4), 629-649. https://doi.org/10.1016/S0305750X(98)00161-2.

Agarwal, B. (1997), Environmental action, gender equity and women's participation. Development and Change, 28: 1-44. https://doi.org/10.1111/1467-7660.00033

Albó, X. (2011). Suma qamaña = convivir bien. ¿Cómo medirlo? [Suma qamaña = living together well. How to measure it?] In Farah, I. H., and Vasapollo, L. (Eds.), Vivir bien: ¿Paradigma no capitalista? [Living well - Non-capitalist paradigm?] (pp. 133-144). La Paz: CIDES-UMSA.

Alphandéry, C., Ancel, G., Araujo, A. M., Attias-Donfut, C., Azam, G., Belkaid, A., Moulier-Boutang, Y., et al. (2013). Manifeste convivialiste: Déclaration d'interdépendence. [Convivialist Manifesto: Declaration of Interdependence]. Paris: Le Bord de L'Eau.

Alphandéry, C., Ancel, G., Araujo, A. M., Attias-Donfut, C., Azam, G., Belkaid, A., Brugère, F., et al. (2020). Second manifeste convivialiste: Pour un monde post-néoliberal. Internationale convivialiste. [Second Convivialist Manifesto: For a post-neoliberal World. Convivialists International]. Paris: Actes Sud. English summary

Asiyanbi, A. (2019, August 7). Decolonising the environment: Race, rationalities and crises. Sheffield Institute for International Development blog. http://siid.group.shef.ac.uk/blog/decolonising-theenvironment-race-rationalities-and-crises/.

Asiyanbi, A., \& Lund, J. F. (2020). Policy persistence: REDD+ between stabilization and contestation. Journal of Political Ecology, 27(1), 378-400. https://doi.org/10.2458/v27i1.23493

Atasay, E., \& Bourassa, G. N. (2013). Illich Beyond Illich: Convivial tools for Illichean readings. A Rejoinder to UCLA's 2003 Roundtable on Illich. International Journal of Illich Studies 3(2), 7579.

Barkin, D. (2019). Conviviality. In: A. Kothari, A. Salleh, A. Escobar, F. Demaria, A. Acosta (Eds.), Pluriverse. A post-development dictionary (pp. 136-139). Tulika Books.

Bauman, Z. (2013). Liquid Love: On the frailty of human bonds. Polity.

Bhambra, G. K., Nişancioğlu, K., \& Gebrial, D. (Eds.) (2018). Decolonising the University. Pluto Press.

Borrini-Feyerabend, G., \& Campese, J. (2017). Self-Strengthening ICCAs - Guidance on a process and resources for custodian indigenous peoples and local communities - draft for use by GSI partners. Geneva: The ICCA Consortium.

Börner, J., Baylis, K., Corbera, E., Ezzine-de-Blas, D., Honey-Rosés, J., Persson, U. M., \& Wunder, S. (2017). The effectiveness of payments for environmental services. World Development 96, 359-374. https://doi.org/10.1016/j.worlddev.2017.03.020

Brockington, D., Duffy, R., \& Igoe, J. (2008). Nature unbound: Conservation, capitalism and the future of Protected Areas. Routledge.

Brockington, D., \& Wilkie, D. (2015). Protected areas and poverty. Philosophical Transactions of the Royal Society 370 (1681). https://doi.org/10.1098/rstb.2014.0271 
Büscher, B., \& Fletcher, R. (2019). Towards Convivial Conservation. Conservation and Society 17 (3), 283296. http://doi.org/10.4103/cs.cs_19_75

Büscher, B., \& Fletcher, R. (2020). The conservation revolution: radical ideas for saving nature beyond the Anthropocene. Verso.

Caillé, A., Humbert, M., Latouche, S., \& Viveret, P. (2011). De la convivialité. Dialogues sur la société conviviale à venir [On conviviality. Dialogues on the convivial society which is to come]. Paris: La Découverte.

Castree, N., \& Nash, C. (2004). Themed essay and responses on posthumanism. Environment and Planning A, 36(9), 1341-1363.

Chasek, P. S., \& Wagner, L. M. (2016). Breaking the mold: a new type of multilateral sustainable development negotiation. International Environmental Agreements: Politics, Law and Economics 16 (3), 397-413.

Chemhuru, M. (2019). Interpreting ecofeminist environmentalism in African communitarian philosophy and Ubuntu: An Alternative to Anthropocentrism. Philosophical Papers, 48:2, 241264, https://doi.org/10.1080/05568641.2018.1450643

Chibvongodze, D. T. (2016). Ubuntu is not only about the human! An analysis of the role of African philosophy and ethics in environment management. Journal of Human Ecology 53 (2), 157-166. https://doi.org/10.1080/09709274.2016.11906968

Chilisa, B. (2017). Decolonising transdisciplinary research approaches: an African perspective for enhancing knowledge integration in sustainability science. Sustainability Science 12 (5), 813-827. https://doi.org/10.1007/s11625-017-0461-1

Chua, L., Harrison, M. E., Fair, H., Milne, S., Palmer, A., Rubis, J., Thung, P., Wich, S., et al. (2020). Conservation and the social sciences: Beyond critique and co-optation. A case study from orangutan conservation. People and Nature, 2, 42-60. https://doi.org/10.1002/pan3.10072

Collins, Y. A. (2019). Colonial residue: REDD+, territorialisation and the racialized subject in Guyana and Suriname. Geoforum, 106, 38-47. https://doi.org/10.1016/j.geoforum.2019.07.019

Collins, Y. A. (2021). Book Review. Bram Büscher and Robert Fletcher, 'The Conservation Revolution: Radical Ideas for Saving Nature Beyond the Anthropocene.' Antipode 53 (2), March 2021. https://antipodeonline.org/wp-content/uploads/2021/03/Book-review_Collins-on-Buscher-andFletcher.pdf

Collins, Y. A., Maguire-Rajpaul, V. A., Krauss, J. E., Asiyanbi, A. P., Jiménez, A., Mabele, M. B., Alexander-Owen, M. Plotting the coloniality of conservation. Journal of Political Ecology, 28, xx-xx.

Connell, R. (2007). Southern theory: The global dynamics of knowledge in social science. Allen \& Unwin.

Conway, J., \& Singh, J. (2011). Radical democracy in global perspective: notes from the pluriverse. Third World Quarterly 32 (4), 689-706. https://doi.org/10.1080/01436597.2011.570029

Cortez, D. (n.d.) La construcción social del "Buen Vivir" (Sumak Kawsay) en Ecuador. Genealogía del diseno y gestión política de la vida. Programa Andino de Derechos Humanos [The social construction of "Buen Vivir" (Sumak Kawsay) in Ecuador. Geneaology of design and political management of life. Andean Programme for Human Rights]. https://repositorio.uasb.edu.ec/bitstream/10644/2788/1/RAA28\%20Cortez,\%20La\%20construcción\%20social\%20del\%20Buen.pdf

Cronon, W. (1996). The trouble with wilderness: or, getting back to the wrong nature. Environmental History 1 (1), 7-28.

Demaria, F. \& Kothari, A. (2017). The Post-Development Dictionary agenda: paths to the pluriverse. Third World Quarterly 38(12), 2588-2599. https://doi.org/10.1080/01436597.2017.1350821

Deriu, M. (2014). Conviviality. In G. D'Alisa, F. Demaria and G. Kallis (Eds.), Degrowth - A vocabulary for a new era (pp. 54-58). Routledge.

Diaz, S., Settele, J., Brondizio, E., Ngo, H.T., Guèze, M., Agard, J., Arneth, A., et al. (2019). 2019. Summary for policymakers of the global assessment report on biodiversity and ecosystem services of the 
Intergovernmental Science-Policy Platform on Biodiversity and Ecosystem Services. https://www.ipbes.net/system/tdf/ipbes_7_10_add-1__advance_0.pdf?file=1\&type=node\&id=35245

Dirlik, A. (2007). Global South: Predicament and promise. The Global South, 1(1), 12-23.

Domínguez, L., \& Luoma, C. (2020). Decolonising conservation policy: How colonial land and conservation ideologies persist and perpetuate indigenous injustices at the expense of the environment. Land, 9 (3), 65. https://doi.org/10.3390/land9030065

Duffy, R. (2014). Interactive elephants: Nature, tourism and neoliberalism. Annals of Tourism Research 44, 88-101. https://doi.org/10.1016/j.annals.2013.09.003

Duffy, R., Massé, F., Smidt, E., Marijnen, E., Büscher, B., Verweijen, J., Ramutsindela, M., Simlai, T., Joanny, L., \& Lunstrum, E. (2019). Why we must question the militarisation of conservation. Biological Conservation 232, 66-73. https://doi.org/10.1016/j.biocon.2019.01.013

Escobar, A. (2011). Sustainability: Design for the pluriverse. Development 54 (2), 137-140.

Espejo, R. (2011). Humanismo radical, decrecimiento y energia [Radical humanism, degrowth and energy]. In: Ivan Illich - La convivencialidad. Virus editorial, 22-44.

Ewuoso, C., \& Hall, S. (2019). Core aspects of Ubuntu: a systematic review. South African Journal of Bioethics Law 12 (2): 93-103. https://doi.org/10.7196/SAJBL.2019.v12i2.679

Fanon, F. (1963). The wretched of the earth. Grove Press.

Fanon, F. (2002). Les damnés de la terre [The damned of the earth]. La Découverte, réédition.

Freire, P. (1987). Literacy: Reading the word and the world. Bergin and Garvey.

Garcia, S. N. O. (2009). El desafío bioético de la era planetaria: La convivencialidad [The bioethical challenge of the planetary era: conviviality]. Revista Latinoamericana de Bioética, Julio-Diciembre 2009, 42-61. https://www.redalyc.org/pdf/1270/127020306004.pdf

Giarracca, N. (2010). "Espacios de esperanza" y "buen vivir" ["Spaces of hope" and "buen vivir"]. https://www.biodiversidadla.org/Noticias/Espacios_de_esperanza_y_buen_vivir

Gintis, H. (1972). Towards a political economy of education: A radical critique of Ivan Illich's Deschooling Society. Harvard Educational Review 42 (1), 70-96.

Gupta, J. \& Vegelin, C. (2016). Sustainable development goals and inclusive development. International Environmental Agreements: Politics, Law and Economics, 16(3), 433-448. https://doi.org/10.1007/s10784-016-9323-z

Hajjar, R., Oldekop, J. A., Cronkleton, P., Newton, P., Russell, A. J. M. \& Zhou, W. (2021). A global analysis of the social and environmental outcomes of community forests. Nature Sustainability 4, 216-224. https://doi.org/10.1038/s41893-020-00633-y

Hall, S. (1992) The West and the Rest: Discourse and power. In T. Das Gupta, C.E. James, C. Andersen, G.E. Galabuzi, \& R. C. A. Maaka (Eds). Race and racialization: essential readings (pp. 85-94). Toronto: Canadian Scholars.

Hart, I. (2001). Deschooling and the Web: Ivan Illich 30 years on. Educational Media International, 38: 23, 69-76. https://doi.org/10.1080/09523980110041449a

Hidalgo-Capitán, A. L. \& Cubillo-Guevara, A. P. (2017). Deconstrucción y genealogía del 'buen vivir' latinoamericano [Deconstruction and genealogy of Latin American 'Buen vivir'. International Development Policy | Revue internationale de politique de développement 9; DOI: https://doi.org/10.4000/poldev.2517

Hidalgo-Capitán, A.L., García-Álvarez, S., Cubillo-Guevara, A.P., \& Medina-Carranco, N. (2019) Los Objetivos del Buen Vivir: Una propuesta alternative a los Objetivos de Desarrollo Sostenible [The Good Living Goals: an alternative proposal to the Sustainable Development Goals]. Revista Iberoamericana de Estudios de Desarrollo/Iberoamerican Journal of Development Studies 8 (1), 657. http://doi.org/10.26754/ojs_ried/ijds.354

Hinchliffe, S. \& Whatmore, S. (2006). Living cities: Towards a politics of conviviality. Science as Culture, 15:2, 123-138. https://doi.org/10.1080/09505430600707988 
Hope, J. (2020a). The anti-politics of sustainable development: Environmental critique from assemblage thinking in Bolivia, Transactions of the Institute of British Geographers 46, 1, 208-222. https://doi.org/10.1111/tran.12409

Hope, J. (2020b). Globalising Sustainable Development: decolonial disruptions and environmental justice in Bolivia. Area. https://doi.org/10.1111/area.12626

Hornedo, B. (2002). Ivan Illich. Hacia una sociedad convivencial [Ivan Illich. Towards a convivial society]. In: Ivan Illich - La convivencialidad (pp. 22-44). Barcelona: Virus Editorial.

Humbert, M. (2017). Convivialism: Reframing Society and Economy. Queen Mary University of London, Second Radical Social Innovation Symposium. http://altersocietal.org/documents/convivial/princ/MH254-Convivialism\%20Reframing-2017-pdfppt.pdf

Ibrahim, H. O. (2018). Q\&A: Getting indigenous women's voices heard on the SDGs. https://www.iied.org/qa-getting-indigenous-womens-voices-heard-sdgs

Illich, I. (1971). Deschooling society. Harper and Row.

Illich, I. (1973). Tools for conviviality. Harper and Row.

Inman, P. L. (1999). An intellectual biography of Ivan Illich. PhD dissertation. Doctor of Education, Northern Illinois University. https://files.eric.ed.gov/fulltext/ED458393.pdf

Indigenous Peoples' Major Group (2015). Position Paper on Proposed SDG Indicators (PDF). https://www.forestpeoples.org/sites/fpp/files/publication/2015/10/sdg-indicatorsfinal-web1.pdf

Isaacson, W. (2014). The Innovators: How a group of hackers, geniuses, and geeks created the digital revolution. Simon and Schuster.

Janaszek, B. (2010). Convivial software (or, why open source matters). https://www.cardus.ca/comment/article/convivial-software-or-why-open-source-matters/

Kasaona, J. K. (2020). From poacher's son to conservation leader: Defending Namibia's community conservation story; 9 October 2020. http://conservationnamibia.com/blog/b2020-poacherconservation-leader.php

Kiwango, W. \& Mabele, M. B. (under review). Convivial Conservation: prospects and challenges. Conservation \& Society, Special Section: Critiquing convivial conservation in theory and practice.

Kothari, A. (2021). Half-Earth or Whole-Earth? Green or transformative recovery? Where are the voices from the Global South? Oryx, 55(2), 161-162. doi:10.1017/S0030605321000120

Krauss, J. E. (under review) Unpacking SDG 15, its targets and indicators: tracing trajectories of conservation thinking.

Krauss, J. E., Jiménez Cisneros, A., \& Requena, M. (under review). Mapping the Sustainable Development Goal System: connections, Eurocentric framings and equity in SDGs 8, 9, 12, 13 and 15.

Lang, C. (2018, October 17). Colonialism vs. Conservation. http://www.conservationwatch.org/2018/10/17/colonialism-vs-conservation/

Langdon, J. (2013). Decolonising development studies: Reflections on critical pedagogies in action. Canadian Journal of Development Studies / Revue canadienne d'études du développement, 34(3), 384-399, https://doi.org/10.1080/02255189.2013.825205

Le Grange, L. (2019). Ubuntu. In A. Kothari, A. Salleh, A. Escobar, F. Demaria, and A. Acosta (Eds.), Pluriverse: a post-development dictionary (pp. 323-326). Tulika Books.

Lim, M. M. L., Jørgensen, P. S., \& Wyborn, C. A. (2018) Reframing the sustainable development goals to achieve sustainable development in the Anthropocene-a systems approach. Ecology and Society 23 (3): 22. https://doi.org/10.5751/ES-10182-230322

Long, G. (2018). How should civil society stakeholders report their contribution to the implementation of the 2030 Agenda for Sustainable Development? United Nations Division for Sustainable Development (UNDESA).

Lorimer, J. (2010). Elephants as companion species: The lively biogeographies of Asian elephant conservation in Sri Lanka. Transactions of the Institute of British Geographers 35(4), 491-506. 
Lugones, M. (2010). toward a decolonial feminism. Hypatia, 25(4), 742-759. http:doi.org/10.1111/j.15272001.2010.01137.x

Lugones, M. (2020). Gender and universality in colonial methodology. Critical Philosophy of Race, 8(1-2), 25-47. http://doi.org/10.5325/critphilrace.8.1-2.0025

Lund, J. F., Sungusia, E., Mabele, M. B., \& Scheba, A. (2017). Promising change, delivering continuity: REDD+ as conservation fad. World Development 89, 124-139. https://doi.org/10.1016/J.WORLDDEV.2016.08.005

Mabele, M. B., Krauss, J. E. \& Kiwango, W. (under review). Going back to the roots: Ubuntu and the support for socio-ecologically just conservation in Southern Africa.

Madianou, M. (2019) Technocolonialism: Digital innovation and data practices in the humanitarian response to refugee crises. Social Media + Society, July-September 2019, 1-13. https://doi.org/10.1177\%2F2056305119863146

Maldonado-Torres, N. (2007). On the coloniality of being: Contributions to the development of a concept. Cultural Studies, 21, 240-270. https://doi.org/10.1080/09502380601162548.

Maldonado-Torres, N. (2016). Outline of ten theses on coloniality and decoloniality. Fondation Frantz Fanon. http://caribbeanstudiesassociation.org/docs/Maldonado-Torres_Outline_Ten_Theses-10.23.16.pdf

Martin, A., Armijos, M. T., Coolsaet, B., Dawson, N., Edwards, G. A. S., Few, R., Gross-Camp, N. et al. (2020). Environmental justice and transformations to sustainability. Environment: Science and Policy for Sustainable Development 62 (6), https://doi.org/10.1080/00139157.2020.1820294

Marvier, M., Kareiva, P., \& Lalasz, R. (2012). Conservation in the Anthropocene: Beyond Solitude and Fragility. The Breakthrough 2. https://thebreakthrough.org/journal/issue-2/conservation-in-theanthropocene

Massarella, K., Krauss, J. E., Kiwango, W. \& Fletcher, R. (forthcoming). Special Section: Critiquing convivial conservation in theory and practice: exploring the possibilities and challenges for a transformative approach to biodiversity conservation. Conservation \& Society.

Mbaria, J., \& Ogada, M. (2016). The big conservation lie. Lens\&Lens Publishing.

Mbembe, A. J. (2016). Decolonizing the university: New directions. Arts and Humanities in Higher Education 15(1), 29-45.

Menton, M., Larrea, C., Latorre, S., Martinez-Alier, J., Peck, M., Temper, L. \& Walter, M. (2020) Environmental justice and the SDGs: from synergies to gaps and contradictions. Sustainability Science. https://doi.org/10.1007/s11625-020-00789-8

Meinzen-Dick, R. \& Zwarteveen, M. (2001). Gender dimensions of community resource management: The case of Water Users' Associations in South Asia. In A. Agrawal and C.C. Gibson (Eds.), Communities and the Environment: Ethnicity, Gender and the State in Community-Based Conservation (pp. 63-88). Rutgers University Press.

Mert, A. (2015). Environmental governance through partnerships. Edward Elgar.

Mignolo, W. D. \& Escobar, A. (Eds.). (2015). Globalization and the decolonial option. Routledge.

Moosavi, L. (2020) The decolonial bandwagon and the dangers of intellectual decolonisation, International Review of Sociology 30 (2), 332-354. https://doi.org/10.1080/03906701.2020.1776919

Mukadasi, B. \& Nabalegwa, M. (2007), Gender mainstreaming and community participation in plant resource conservation in Buzaya county, Kamuli district, Uganda. African Journal of Ecology, 45: 712. https://doi.org/10.1111/j.1365-2028.2007.00730.x

Naicker, I. (2011). The search for universal responsibility: The cosmovision of Ubuntu and the humanism of Fanon. Development 54(4), 455-460.

Narodowski, M. \& Botta, M. (2017). La mayor disrupción posible en la historia de la pedagogía moderna: Ivan Illich [The biggest disruption possible in the History of Pedagogy: Ivan Illich]. Pedagogía y Saberes, 46, 45-54. https://revistas.pedagogica.edu.co/index.php/PYS/article/view/5227 
Noe, C. \& Kangalawe, R. Y. M. (2015). Wildlife protection, community participation in conservation, and (dis)empowerment in Southern Tanzania. Conservation and Society 13(3), 244-253. http://doi.org/ $\underline{10.4103 / 0972-4923.170396}$

Noe, C. (2019). The Berlin curse in Tanzania: (re)making of the Selous World Heritage Property. South African Geographical Journal. 101(3), 379-398. http://doi.org/10.1080/03736245.2019.1645039

Noxolo, P. (2017). Introduction: Decolonising geographical knowledge in a colonised and re-colonising postcolonial world. Area 49, 317-319. https://doi.org/10.1111/area.12370.

Ogada, M. (2017, July 28). The Big Conservation Lie: Overview and interview with the authors. National Geographic [Blog]. https://blog.nationalgeographic.org/2017/07/28/the-big-conservation-lieoverview-and-interview-with-the-authors/

Ogada, M. (2019, June 27). Decolonising conservation. It is about the land, stupid! https://www.theelephant.info/culture/2019/06/27/decolonising-conservation-it-is-about-the-landstupid/

Olvera, R. \& Márquez, J. (n.d.) Ivan Illich - Su vida [His life; PDF]. https://www.ivanillich.org.mx/IllichAntologia.pdf

Paulson, W. (2001). For a cosmopolitical philology: lessons from science studies. Substance, 30(3): 101-119.

Plumwood, V. (2003). Colonization, Eurocentrism and Anthropocentrism. In W.M. Adams \& M. Mulligan (Eds.), Decolonizing nature: Strategies for Conservation in a Post-Colonial Era (pp. 51-78). Earthscan.

Pradhan, P., Costa, L., Rybski, D., Lucht, W., and J.P. Kropp (2017). A systematic study of Sustainable Development Goal (SDG) interactions. Earth's Future 5, 1169-1179, https://doi.org/10.1002/2017EF000632

Quijano, A. (2000). Coloniality of power and Eurocentrism in Latin America. International Sociology, 15, 215-232. https://doi.org/10.1177/0268580900015002005

Quijano, A. (2007) Coloniality and modernity/rationality. Cultural Studies, 21 (2-3), pp. 168178, http://doi.org/10.1080/09502380601164353

Rodríguez, J. P., Taber, A. B., Daszak, P., Sukumar, R., Valladares-Padua, C., Padua, S., Aguirre, L. F., Medellín, R. A., et al. (2007). Globalization of Conservation: A view from the South. Science 317 (5839), 755-756. http://doi.org/10.1126/science.1145560

Rubis, J. M., \& Theriault, N. (2019). Concealing protocols: Conservation, Indigenous survivance, and the dilemmas of visibility. Social and Cultural Geography, 21(7), pp. 962-944. https://doi.org/10.1080/14649365.2019.1574882

Salleh, A. (2016). Climate, water, and livelihood skills: A Post-Development reading of the SDGs. Globalizations, 13(6), 952-959. https://doi.org/10.1080/14747731.2016.1173375

Sandbrook, C., Fisher, J. A., Holmes, G., Luque-Lora, R. \& Keane, A. (2019). The global conservation movement is diverse but not divided. Nature Sustainability 2(4), 316-323.

Santos, B. (2018). Decolonising the university: The challenges of deep cognitive justice. Cambridge Scholars Publishing.

Schulz, K. A. (2017). Decolonizing political ecology: ontology, technology and 'critical' enchantment. Journal of Political Ecology 24(1), 125-143. https://doi.org/10.2458/v24i1.20789

Shackeroff, J., \& Campbell, L. (2007). Traditional Ecological Knowledge in conservation research: problems and prospects for their constructive engagement. Conservation and Society 5, 343-360.

Shizha, E. (2016). African Indigenous perspectives on technology. In: G. Emeagwali and E. Shizha (Eds.), African Indigenous knowledges and the sciences: Journeys into the past and present (pp. 47-64). Sense Publishers.

Spann, M. (2017). Politics of poverty: The post-2015 Sustainable Development Goals and the business of agriculture. Globalizations 14(3), 360-378. https://doi.org/10.1080/14747731.2017.1286169

Survival International (2018). Colonialism vs. conservation [Video]. https://vimeo.com/295143710 
Sundberg, J. (2004). Identities in the making: conservation, gender and race in the Maya Biosphere Reserve, Guatemala. Gender, Place \& Culture 11(1), 43-66. https://doi.org/10.1080/0966369042000188549

Tallis, H., Lubchenco, J. and 238 co-signatories. (2014). Working together: A call for inclusive conservation. Nature 515(7527), 27-28.

Terblanché-Greeff, A.C. (2019). Ubuntu and environmental ethics: The West can learn from Africa when faced with climate change. In M. Chemhuru (Ed.) African environmental ethics (pp. 93-110). Springer Nature.

Tlostanova, M. \& Mignolo, W. (2009). Global coloniality and the decolonial option. Kult 6, 130-147. http://postkolonial.dk/artikler/kult_6/MIGNOLO-TLOSTANOVA.pdf

Toomey, A.H. (2020). The making of a conservation landscape: Towards a practice of interdependence. Conservation and Society 18, 25-36. http://doi.org/10.4103/cs.cs_18_115

Toporek, R. (2013). Social class, classism, and social justice. In W. M. Liu (Ed.) The Oxford Handbook of social class in counselling (pp. 21-34). Oxford University Press.

Tran, T. C., Ban, N. C., \& Bhattacharyya, J. (2020) A review of successes, challenges, and lessons from Indigenous protected and conserved areas. Biological Conservation 241, 108271. https://doi.org/10.1016/j.biocon.2019.108271

Tuck, E. \& Yang, K. W. (2012). Decolonization is not a metaphor. Decolonization: Indigeneity, Education and Society 1 (1), 1-40.

Tuhiwai Smith, L. (1999). Decolonizing methodologies: Research and Indigenous Peoples. Zed.

Tumusiime, D.M. \& Vedeld, P. (2012). False promise or false premise? Using tourism revenue sharing to promote conservation and poverty reduction in Uganda. Conservation and Society 10(1), 15. http://doi.org/10.4103/0972-4923.92189

UN - United Nations (2015). Transforming our world: the 2030 Agenda for Sustainable Development. Resolution 70/1 Adopted by The General Assembly on 25 September 2015. https://www.un.org/ga/search/view_doc.asp?symbol=A/RES/70/1\&Lang=E

UN - United Nations (2018). Global indicator framework for the Sustainable Development Goals and targets of the 2030 Agenda for Sustainable Development. https://unstats.un.org/sdgs/indicators/Global\%20Indicator\%20Framework\%20after\%20refinement_En g.pdf

Vizenor, G. R. (1998). Fugitive poses: Native American Indian scenes of absence and presence. University of Nebraska Press.

Wa Ngugi, M. (2012). Rethinking the Global South. The Global South Project. http://www.globalsouthproject.cornell.edu/rethinking-the-global-south.html

Weber, H. (2017). Politics of 'Leaving No One Behind': Contesting the 2030 Sustainable Development Goals Agenda, Globalizations, 14 (3), 399-414. https://doi.org/10.1080/14747731.2016.1275404

WCED. (1987). Our Common Future - Report by World Commission on Environment and Development. Oxford University Press.

Wuerthner, G., Crist, E., \& Butler, T. (Eds.). (2015). Keeping the wild: Against the domestication of Earth. Island Press.

Zaid, G. (2011). Illich el removedor [Illich the remover]. https://www.letraslibres.com/mexico-espana/illichel-removedor

Zafra-Calvo, N., Pascual, U., Brockington, D., Coolsaet, B., Cortes-Vazquez, J.A., Gross-Camp, N., Palomo, I. \& Burgess, N. D. (2017). Towards an indicator system to assess equitable management in protected areas. Biological Conservation 211, 134-141. https://doi.org/10.1016/j.biocon.2017.05.014

Zanotti, L., Carothers, C., Aqpik Apok, C., Huang, S., Coleman, J., and C. Ambrozek (2020). Political ecology and decolonial research: co-production with the Iñupiat in Utqiagivik. Journal of Political Ecology 27 (1), pp. 43-66. https://doi.org/10.2458/v27i1.23335 